\title{
RISK ANALYSIS OF SELECTED SOFT TARGET
}

\author{
Ing. Ondrej Zimek \\ doc. Ing. Martin Hromada, Ph.D. \\ Tomas Bata University in Zlin, Faculty of Applied Informatics, Czech Republic
}

\begin{abstract}
The aim of this article is to create a risk analysis of selected school facilities which can be an auxiliary tool of security solutions against terrorism. Most terrorist attacks are focused on so-called soft targets - crowded places, which are not secure against violent attacks. Furthermore, attacks on school facilities abroad are frequent too. A wellprepared risk analysis is a necessary method to detect weaknesses and strengths of the security of a soft target. The university in Zlin in the Czech Republic was chosen as a Soft Target for this research. The paper deals with a risk analysis that was created by the Ministry of the Interior of the Czech Republic methodology. The methodology deals with these main variables - Performing an Attack, Place of Attack, Time of Attack, Likelihood, and Impact. The result of the risk analysis is a degree of threat which shows a possible risk of the university. The risk analysis shows that the highest value of the degree of threat represents shooting inside university during the daily working time. On the other hand, the minimum value of the degree of threat represents shooting in front of the university during the event of invited. In keeping with the weaknesses which represents the value of the degree of threat under the acceptable risk level, we should protect the soft target as well as possible. Due to the protection of the specific weaknesses should be soft targets safer. This methodology is one of the ways how to prepare a risk analysis of a soft target.
\end{abstract}

Keywords: safety, risk analysis, soft targets, terrorism, security

\section{INTRODUCTION}

Terrorism threatens humanity for a very long time. [1] Targets and modus operandi of terrorist attacks are still changed. The author [2] mentioned that do-it-yourself (DIY) attack are increasing across Europe, North America, and the Middle East. Nowadays, most terrorist attacks are focused on crowded places that are not secure against violent attacks or its security has a very low level. [3] These places are labelled as Soft Targets. [4] The opposite of soft targets are so called hard targets, which have high-security precautions against violent attacks. Military facilities or government facilities are examples of so-called hard targets. [5] As soft targets are labelled following examples:

- school facilities,

- train or bus stations,

- religious monuments, 
- hotels,

- shopping malls,

- bars or clubs,

- square,

- cinemas or theatres,

- sport halls,

- $\quad$ etc. [6], [7], [8], [9]

Terrorist attacks on soft targets in the last years were most common. For example, there are terrorist attacks aimed on soft targets in the last three years: Christchurch in New Zealand 2019 (mosque), Nairobi in Kenya 2019 (hotel), Sri Lanka 2019 (church), Halle in Germany 2019 (synagogue), London in United Kingdom 2019 (bridge), Carcassonne and Trebes in France 2018 (car, supermarket), Strasbourg in France 2018 (Christmas market), Bir-al-Abed in Egypt 2017 (mosque) [10]. Typically, most of the attacks on school facilities were in the USA, however, these attacks increased abroad in recent years also. There are examples of these attacks: Naples Florida in the USA 2019, Blagoveshchensk in Russia 2019, Kuopio in Finland 2019, Volsk in Russia 2019, Suzano in Brazil 2019, Parkland, Florida in the USA 2018, Shaanxi in China, 2018, Benton Kentucky in the USA 2018, Aztec New Mexico in the USA2 2017, Grasse in France 2017 [11]. As can be seen, a lot of attacks were focused on so called soft targets and a lot of attacks were focused specifically on school facilities. Due to these reasons, the University in Zlin was chosen as the soft target for risk analysis. Problematics about secure soft targets are solved in government documents as Strategy of the Czech Republic for Combating Terrorism from 2013, Terrorism Situation and Trend Report 2019 (TE-SAT) EU, or Crowded Places Guidance (United Kingdom). The first step to make an effective security solution for protecting a soft target is a well-prepared risk analysis. The Ministry of the Interior of Czech Republic methodology "Basics of Soft Target Protection Guidelines" and "Evaluation of Soft Target Vulnerability" was chosen for this paper.

\section{RISK ANALYSIS}

A risk analysis is a necessary method to detect weaknesses and strengths of a soft target. The analysis evaluates the most dangerous situations which should be secured. The Ministry of the Interior of the Czech Republic methodology was selected for this study.

The risk analysis is separated into two auxiliary tables and one main table. The first of them describes the likelihood of an attack. The next table determines the impact of an attack. And the last of them evaluates the degree of threat.

As can be seen, the likelihood is determined as accessibility, obstacles, and desirability. Moreover, each of these categories is separated into seven points, where point one represents a minimal likelihood. On the opposite, the category with the seven points represents the highest likelihood. The points will be used in the main table to calculate the degree of threat. 
Table 1 Auxiliary table Likelihood [3]

\begin{tabular}{|c|c|c|c|}
\hline \multicolumn{4}{|c|}{ Likelihood } \\
\hline $\mathbf{P .}$ & Accessibility & Obstacles & Desirability \\
\hline 7 & Without arms & $\begin{array}{l}\text { An individual without the } \\
\text { assistance of other people, a public } \\
\text { place }\end{array}$ & $\begin{array}{l}\text { It has already occurred } \\
\text { many times in the Czech } \\
\text { Republic }\end{array}$ \\
\hline 6 & Commonly available (knife) & $\begin{array}{l}\text { It requires the involvement of } \\
\text { more people, a public place }\end{array}$ & $\begin{array}{l}\text { It has been in the relevant } \\
\text { foreign country many times }\end{array}$ \\
\hline 5 & $\begin{array}{l}\text { More commonly available } \\
\text { weapons, a weapon of less } \\
\text { commonly available (car) }\end{array}$ & $\begin{array}{l}\text { Simple or one-off cooperation with } \\
\text { local criminal } \\
\text { a group, a public place }\end{array}$ & $\begin{array}{l}\text { It has appeared several } \\
\text { times in the Czech } \\
\text { Republic }\end{array}$ \\
\hline 4 & $\begin{array}{l}\text { Gun on Permit or More, } \\
\text { (Firearm) }\end{array}$ & $\begin{array}{l}\text { More complicated or longer-term } \\
\text { cooperation with the criminal } \\
\text { group of the public is inaccessible }\end{array}$ & $\begin{array}{l}\text { It has appeared several } \\
\text { times in relevant foreign } \\
\text { countries }\end{array}$ \\
\hline 3 & $\begin{array}{l}\text { A weapon obtainable by } \\
\text { criminal activity (black market, } \\
\text { etc.) without the need for } \\
\text { professional training }\end{array}$ & $\begin{array}{l}\text { One-time talks with a local } \\
\text { terrorist group, a public } \\
\text { inaccessible place }\end{array}$ & $\begin{array}{l}\text { It occurred rarely in the } \\
\text { Czech Republic }\end{array}$ \\
\hline 2 & $\begin{array}{l}\text { A weapon that can be acquired } \\
\text { by criminal activities with the } \\
\text { need for professional training } \\
\text { with short delivery times }\end{array}$ & $\begin{array}{l}\text { Coordinated actions at the local } \\
\text { level with cooperation with a } \\
\text { terrorist group, public inaccessible } \\
\text { place }\end{array}$ & $\begin{array}{l}\text { It has rarely occurred in the } \\
\text { relevant foreign countries }\end{array}$ \\
\hline 1 & $\begin{array}{l}\text { The weapon can be obtained by } \\
\text { criminal activity with the need } \\
\text { for professional training and } \\
\text { long delivery times }\end{array}$ & $\begin{array}{l}\text { Internationally coordinated action } \\
\text { by a terrorist group, accessible to } \\
\text { the public or inaccessible to the } \\
\text { public }\end{array}$ & $\begin{array}{l}\text { It never appeared in the } \\
\text { Czech Republic or in the } \\
\text { relevant foreign countries }\end{array}$ \\
\hline
\end{tabular}

Table 2 shows the impact of an attack. As can be seen, the impact is determined as damage to building, threat to lives, impact on community, and economical losses. The value of impact is defined into seven points as the previous table, where point one represents a minimal impact. On the other hand, the category with the seven points represents the highest impact. 
Table 2 Auxiliary table - Impact [3]

\begin{tabular}{|c|c|c|c|c|}
\hline \multicolumn{5}{|c|}{ Impact } \\
\hline $\mathbf{P}$. & Damage to building & Threat to lives & \begin{tabular}{|l|} 
Impact on community \\
\end{tabular} & Economical losses \\
\hline 7 & $\begin{array}{l}\text { Destruction of the object, } \\
\text { eventually static } \\
\text { disruption, cancellation of } \\
\text { the event }\end{array}$ & $\begin{array}{l}\text { Serious injuries to } \\
\text { more people and the } \\
\text { death of more people }\end{array}$ & $\begin{array}{l}\text { Termination of } \\
\text { participation / activity }\end{array}$ & $\begin{array}{l}\text { Impact } \\
\text { economically } \\
\text { liquidated }\end{array}$ \\
\hline 6 & $\begin{array}{l}\text { Extensive limitation of } \\
\text { the functionality of an } \\
\text { object or possibility of } \\
\text { organizing an event }\end{array}$ & $\begin{array}{l}\text { Serious injuries to } \\
\text { more people and death } \\
\text { of individuals }\end{array}$ & $\begin{array}{l}\text { Temporary interruption } \\
\text { of activity }\end{array}$ & $\begin{array}{l}\text { Impact over CZK } \\
500,000, \text { insurable } \\
\text { by insurance }\end{array}$ \\
\hline 5 & $\begin{array}{l}\text { Limit the functionality of } \\
\text { part of the object or part } \\
\text { of the action }\end{array}$ & $\begin{array}{l}\text { Serious injuries to } \\
\text { more people }\end{array}$ & $\begin{array}{l}\text { Real risk of people } \\
\text { being involved in other } \\
\text { activities }\end{array}$ & $\begin{array}{l}\text { Impact over CZK } \\
100,000, \text { insurable } \\
\text { by insurance }\end{array}$ \\
\hline 4 & $\begin{array}{l}\text { Local limitation of the } \\
\text { functionality of the room } \\
\text { or part of the action }\end{array}$ & $\begin{array}{l}\text { Serious injury to } \\
\text { individuals }\end{array}$ & $\begin{array}{l}\text { General concern to be } \\
\text { active in the } \\
\text { community, more } \\
\text { limitation of activities }\end{array}$ & $\begin{array}{l}\text { Impact over CZK } \\
100,000, \text { solvable } \\
\text { by insurance }\end{array}$ \\
\hline 3 & $\begin{array}{l}\text { Serious damage to the } \\
\text { object or disturbance of } \\
\text { the action without } \\
\text { limitation of functionality }\end{array}$ & $\begin{array}{l}\text { Light injuries to more } \\
\text { people }\end{array}$ & Less activity restrictions & $\begin{array}{l}\text { Impact in the order } \\
\text { of tens of thousands }\end{array}$ \\
\hline 2 & $\begin{array}{l}\text { Minor damage to the } \\
\text { object or disturbance of } \\
\text { the action without } \\
\text { limitation of functionality }\end{array}$ & $\begin{array}{l}\text { Light injuries to } \\
\text { individuals }\end{array}$ & $\begin{array}{l}\text { Poor impact on } \\
\text { individuals }\end{array}$ & Impact to $5000 \mathrm{CZK}$ \\
\hline 1 & $\begin{array}{l}\text { No or negligible object } \\
\text { damage or action } \\
\text { disruption }\end{array}$ & $\begin{array}{l}\text { Shock or minor } \\
\text { injuries }\end{array}$ & $\begin{array}{l}\text { Without an obvious } \\
\text { impact on the } \\
\text { community }\end{array}$ & $\begin{array}{l}\text { No impact, or } \\
\text { negligible }\end{array}$ \\
\hline
\end{tabular}

Table 3 shows the main table of risk analysis. The degree of threat is calculated in this table. Table 3 is separated into several columns. The first step is to determine to perform an attack. In this study were chosen the most common situations as shooting, knife attack, attack by car, and bomb attack. Place of attack was separated into two possibilities - attack in front of the university, and inside of the university. Next, the time of attack represents attack during daily working time or during the event for invited. The following values of likelihood and impact were chosen by auxiliary table 1 and table 2 . 
Table 3 Risk analysis of the university

\begin{tabular}{|c|c|c|c|c|c|c|c|c|c|c|c|c|}
\hline \multirow[b]{2}{*}{$\begin{array}{c}\text { Performing } \\
\text { an attack }\end{array}$} & \multirow[b]{2}{*}{$\begin{array}{c}\text { Place } \\
\text { of attack }\end{array}$} & \multirow[b]{2}{*}{ Time of attack } & \multicolumn{4}{|c|}{ Likelihood } & \multicolumn{5}{|c|}{ Impact } & \multirow[b]{2}{*}{ 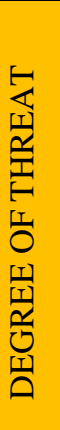 } \\
\hline & & & 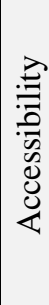 & $\begin{array}{l}\frac{\tilde{\sigma}}{0} \\
\frac{\pi}{0} \\
0 \\
0\end{array}$ & 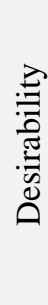 & 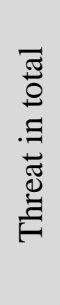 & 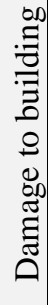 & 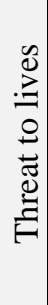 & 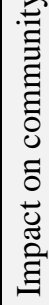 & 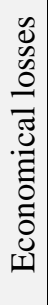 & 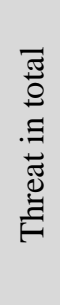 & \\
\hline Shooting & In front of & Daily working time & 3 & 7 & 2 & 12 & 2 & 6 & 4 & 4 & 16 & 192 \\
\hline Shooting & In front of & Event for invited & 3 & 7 & 2 & 12 & 2 & 6 & 3 & 3 & 14 & 168 \\
\hline Shooting & Inside & Daily working time & 3 & 7 & 6 & 16 & 5 & 7 & 4 & 4 & 20 & 320 \\
\hline Shooting & Inside & Event for invited & 3 & 7 & 2 & 12 & 5 & 6 & 4 & 3 & 18 & 216 \\
\hline Knife attack & In front of & Daily working time & 6 & 7 & 4 & 17 & 2 & 4 & 4 & 3 & 13 & 221 \\
\hline Knife attack & In front of & Event for invited & 6 & 7 & 2 & 15 & 2 & 4 & 3 & 3 & 12 & 180 \\
\hline Knife attack & Inside & Daily working time & 6 & 7 & 3 & 16 & 2 & 4 & 4 & 3 & 13 & 208 \\
\hline Knife attack & Inside & Event for invited & 6 & 7 & 4 & 17 & 2 & 4 & 3 & 3 & 12 & 204 \\
\hline Attack by car & In front of & Daily working time & 5 & 7 & 2 & 14 & 3 & 6 & 3 & 4 & 16 & 224 \\
\hline Attack by car & In front of & Event for invited & 5 & 7 & 2 & 14 & 3 & 6 & 4 & 4 & 17 & 238 \\
\hline Attack by car & Inside & Daily working time & 5 & 7 & 1 & 13 & 3 & 4 & 4 & 4 & 15 & 195 \\
\hline Attack by car & Inside & Event for invited & 5 & 7 & 1 & 13 & 3 & 4 & 5 & 4 & 16 & 208 \\
\hline Bomb & In front of & Daily working time & 2 & 5 & 2 & 9 & 6 & 7 & 5 & 4 & 22 & 198 \\
\hline Bomb & In front of & Event for invited & 2 & 5 & 2 & 9 & 6 & 7 & 4 & 4 & 21 & 189 \\
\hline Bomb & Inside & Daily working time & 2 & 5 & 2 & 9 & 7 & 6 & 4 & 4 & 21 & 189 \\
\hline Bomb & Inside & Event for invited & 2 & 5 & 2 & 9 & \begin{tabular}{|l|}
7 \\
\end{tabular} & 6 & 5 & 4 & 22 & 198 \\
\hline
\end{tabular}

The total likelihood was calculated according to formula 1 .

$L=x 1+x 2+x 3$

L... Total impact of Likelihood

$\mathbf{x 1}$... Accessibility

$\mathbf{x 2} \ldots$ Obstacles

x3... Desirability 
The total impact was calculated according to formula 2.

$I=y 1+y 2+y 3+y 4$

I... Total value of Impact

y1... Damage to building

y2... Threat to lives

y3... Impact on community

y4... Economical losses

And finally, the degree of threat was calculated according to formula 3.

$D=L \times I$
D... Degree of threat
L... Total impact of Likelihood
I... Total impact of Impact

The maximum value degree of threat is value 588. An acceptable risk level is not determined by the methodology. The author defined the acceptable risk level as a mean value of all variables (Likelihood and Impact) with the value 192.

\section{CONCLUSION}

This paper deals with the fact that the terrorist attacks on so-called soft targets (school facilities, hotels, shopping malls, ...) are most common. Furthermore, the attacks on school facilities are quite frequently too (Charlotte in North Carolina in the USA, Salt Lake City in Utah in the USA, Grasse in France, ...) and trend of so called do-ityourself (DIY) attacks is increasing. For these reasons, the Thomas Bata University in Zlin was selected as an object for this study. The selected soft target was analyzed by the Ministry of the Interior methodology. The methodology deals with these main variables - Performing an Attack, Place of Attack, Time of Attack, Likelihood, and Impact. Moreover, the variables Likelihood and Impact were determined by the auxiliary tables which are part of the methodology. The risk analysis shows that the highest value of the degree of threat represents shooting inside university during the daily working time with the value 320 . On the other hand, the minimum value of the degree of threat represents shooting in front of the university during the event of invited with the value 168. According to the risk analysis, we could identify the weaknesses of the selected soft target and protect the university as well as possible. This methodology is one of the ways how to prepare a risk analysis of a soft target. One of the challenges for future research is to develop a united value for the acceptable risk level. Another next research could be focused on possibilities to protect soft targets. 


\section{ACKNOWLEDGEMENTS}

This article was created with the support of an internal research project of Tomas Bata University in Zlín "Perspective Technologies and Methods for Ensuring Physical Security 2030" (30206003025) and Internal Grant Agency of Tomas Bata University under the project No. IGA/FAI/2020/003.

\section{REFERENCES}

[1] Lapkova, D., Kotek L. and Kralik, L. Soft Targets - Possibilities of Their Identification, Proceedings of the 29th DAAAM International Symposium, pp.03690377, DAAAM International, ISBN 978-3-902734-20-4, ISSN 1726-9679, Vienna 2018, Austria DOI: 10.2507/29th.daaam.proceedings.053

[2] FOREST, James J.F. The Terrorism lectures: a comprehensive collection for the student of terrorism, counterterrorism, and national security. Third edidion. United States of America, Worzalla, Stevens Point: Nortia Press, 2019. ISBN 978-1-940503$16-5$.

[3] Z. Kalvach, Definition of Soft Targets. Prague, 2017.

[4] Benova, Hoskova-Mayerova, Navratil. Terrorist Attacks on Selected Soft Targets. Journal of Security and Sustainability Issues, 2019. doi.org/10.9770/jssi.2019.8.3(13)

[5] Fagel, Michael J. a Jennifer L. Hesterman, ed. Soft targets and crisis management: what emergency planners and security professionals need to know. Boca Raton: CRC Press, Taylor \& Francis Group, 2017. ISBN 978-1-4987-5632-7.

[6] ZIMEK, Ondřej. Security design of selected soft targets. MATEC Web of Conferences: 23rd International Conference on Circuits, Systems, Communications and Computers (CSCC 2019). 2019, (292). DOI: 10.1051/matecconf/201929201038.

[7] Lapkova Dora, Lukas Kotek: Možnosti ochrany měkkých cílů, Fakulta bezpečnostného inžinierstva, Žilinská univerzita, ISBN 978-80-554-1398-3

[8] Lucia Duricova, Martin Hromada and Jan Mrazek. The Proposal of the Software for the Soft Targets Assessment. 2017 International Conference on Soft Computing, Intelligent System and Information Technology. DOI 10.1109/ICSIIT.2017.9

[9] Figuli, Lucia, Zuzana Kubikova and Matus Ivanco. Safety Assesment and Blast Protection of Selected Soft Target. Interdisciplinary Description of Complex Systems 17(1-A), 58-66, 2019. DOI: 10.7906/indecs.17.1.8

[10] List of terrorist incidents. In: Wikipedia: the free encyclopedia. San Francisco (CA): Wikimedia Foundation, 2001-2020, online : https://en.wikipedia.org/wiki/List_of_terrorist_incidents\#1970-present

[11] List of attacks related to secondary schools. In: Wikipedia: the free encyclopedia [online]. San Francisco (CA): Wikimedia Foundation, 2001-2020, online: https://en.wikipedia.org/wiki/List_of_attacks_related_to_secondary_schools 
